\title{
ETOS DAGANG ORANG ISLAM JAWA DAN BUDAYA DAGANG ETNIS CINA DALAM TANTANGAN PENINGKATAN PEREKONOMIAN INDONESIA
}

\author{
Daryono, Dini Anggraheni \\ Fakultas Ekonomi Universitas Semarang \\ daryono@usm.ac.id \\ dinia85@usm.ac.id
}

\begin{abstract}
Abstrak
Penelitian ini bertujuan membuktikan keberhasilan etos dagang orang Islam Jawa dengan nilainilai moral yang sesuai pada masa itu. Penelitian ini adalah penelitian kepustakaan (library research), data bersumber dari berbagai karya para ahli yang menjelaskan kedalaman maksud yang menunjukkan keberhasilan etos dagang. Metode dengan analisis isi (content analysis) dipadukan dengan hermeneutic ilmiah juga pendekatan sosiologis yang bersifat interpretasi sosiologik. Penelitian ini diharapkan bisa memperbaiki dugaan negatif pada etos dagang orang Islam Jawa yang mungkin justru bisa menjadi tantangan peningkatan perekonomian Indonesia sekarang dan yang akan datang.
\end{abstract}

Kata Kunci : Etos , Dagang, Orang Islam, Jawa

\begin{abstract}
This study aims to prove the success of the Javanese Moslem's trade ethos with the moral values of its time. The type of this research is library research; the data are derived from various works of experts which explain the depth of intent that shows the success of its trade ethos. The method used is content analysis combined with scientific hermeneutics as well as sociological approach which is sociological interpretation. This study is expected to improve the negative allegations on the Javanese Moslem's trade ethos which might actually be a challenge to improve the Indonesian economy now and in the future.
\end{abstract}

Keywords: Ethos, Trade, Moslem, Javanese 


\section{A. Pendahuluan}

Istilah "orang Islam Jawa"pada judul tulisan ini. Pertamaistilah itumaksud pengertiannya di sini disamakan dengan istilah obyektivikasi Islam oleh orang Jawa yang beragama Islam dalam hal dagang. Menurut Kuntowidjojo, obyektifikasi Islam adalah sebuah kokretisasi keyakinan yang dihayati secara internal. Suatu perbuatan disebut obyektif jika bisa dirasakan juga oleh orang non-Muslim sebagai sesuatu yang natural atau alamiah dan wajar, tidak sebagai perbuatan keagamaan. Obyektivikasi adalah, perbuatan rasional berbagai nilai yang diwujudkan kedalam perbuatan rasional, sehingga orang luar dapat menikmati atau menerima tanpa harus menyetujui nilai asalnya dari ajaran agama Islam.Misalnya, sikap kesetiakawanan merupakan obyektivikasi Islam dari ukhuwah. ${ }^{1}$ Karenanya, analisa pemahamannya dalam hal itu pada tulisan ini menggunakan pendekatan sosio historis ${ }^{2}$. Kedua,maksud pengertianIslam Jawa di sini bukan sebagai agama Jawa (The Religion of Java) sebagaimana pemikiran Cifford Geertz yang dibagi menjadi tiga aliran: santri, priyayi dan abangan. ${ }^{3}$ Pembagian Gertz itu menyesatkan, karena tidak berdasarkan kriteria yang konsekuen.Dia telah mengkacaukan dua pembagian yang termasuk dalam susunan yang berlainan, telah mencampuradukkan antara pembagian horisontal (hubungan sesama) dengan vertikal (hubungan dengan Tuhan). ${ }^{4}$ Misalnya, priyayi merupakan status atau golongan sosial bagi komunitas Jawa, maka tidak menunjukkan salah satu tradisi keagamaan khusus. Seorang priyayi bisa saja sebagai muslim saleh dan muslim statistik

\footnotetext{
${ }^{1}$ Kuntowidjojo, Identitas Politik Umat Islam (Bandung: Mizan, 1997), hlm. 69-70.

${ }^{2}$ Ada dua pendekatan dalam memahami Islam yaitu, pendekatan sosial historis dan normatif atau doktrinal.Pendekatan sosiol historis selalu berhubungan dengan manusia yang hidup bersama sebagai satu kelompok dalam situasi saling membutuhkan dan berhubungan dengan tingkatan atau aktifitas masyarakat yang hidup dalam kebersamaan (komunitas). Selain itu, pendekatan ini juga berhubungan dengan perkembangan atau evolusi masyarakat dalam aturan kronologi yang tepat yang berdasarkan sejarah, otentik, nyata, factual dan bukan legenda atau fiksi. Sedang pendekatan normative lebih mengacu pada hal-hal yang berkaitan dengan yang baik dan benar, buruk dan salah, bagaimana hidup ini harus dijalani atau apa yang harus dilakukan manusia dalam kondisi tertentu. Sedangkan pada taraf doctrinal, lebih berhubungan dengan doktrin suatu ajaran atau dokma atau dogma tertentu dan juga berhubungan dengan aksi atau tindakan pengajaran. Lihat Jean L Mc Kechnie (ed), Websters New Universal Unabridged Dictionary, (New York: The World Publishing Company), edisi 2, 1972, hlm. 1799.

${ }^{3}$ Clifford Gertz, The Religion of Java, (New York: The Free Press), 1981, hlm. 48.

${ }^{4}$ Zaini Muchtarom, Islam di Jawa dalam Perspektif Santri dan Abangan, (Jakarta: Salemba Diniyah), 2002,
} hlm. 17. 
(santri dan abangan) sekaligus, mereka juga bisa termasuk orang Hindu-Budha atau Kristen. ${ }^{5}$

Mengacu pada berbagai penjelasan pertama dan kedua tersebut, maka Islam Jawa pada tulisan ini kedalaman maksud dan pengertiannya disamakan dengan budaya Jawa. Menurut Hans Antlov, budaya Jawa adalah, sekumpulan ide, norma, keyakinan dan nilai yang sangat beragam sehingga tidak mungkin dapat dilukiskan sebagai "keseluruhan yang padu" yang sama-sama dipakai oleh orang Jawa. Karenanya, memahami budaya Jawa berarti menganalisa distribusi dan reproduksi dari pengetahuan yang demikian beragam di masyarakat Jawa. ${ }^{6}$ Berdasar pengertian tersebut maka, baik istilah orang Islam Jawa maupun Islam Jawa di sini termasuk bagian budaya Jawa dianalisa di pahami sebagai obyektivikasi Islam dengan pendekatan sosio historis khusus dalam hal etos dagangnya.

Analisa penulis dalam hal itu dilatarbelakangi oleh adanya dugaan bahwa, sejak diproklamasikan tahun 1945, Negara Republik Indonesia kurang ada pengusaha pribumi yang asli orang Jawa, meskipunsudah ada berbagai kebijakan Negara untuk memupuk atau meningkatkan prilaku bisnisnya. Dugaan tersebut sebagaimana secara implisit dijelaskan oleh Mochtar Pabottinggi bahwa, para cendikiawan menganggap keterbelakangan bangsa Indonesia, terutama pada bidang ekonomi disebabkan oleh keterbelakangan kebudayaannya dan yang paling banyak dituding penyebabnya adalah budaya Jawa. ${ }^{7}$ nti budaya Jawa sering dituduhatau dicap sebagai yang merusak bagi kegiatan perekonomian. Misalnya, budaya Jawa mengenai rasa ingin memiliki terhadap suatu komunitasnya, seperti pola gotongroyong dan atau sikap feodalnya,di samping dianggap memanjakan juga tidak sesuai atau bertentangan dengan cara orang Barat berdagang. ${ }^{8}$

Mencermati dugaan negatif para cendikiawan tersebut, maka menjadi acuan tujuan penelitian ini dua.Pertama,bagi penulis untuk menganalisa dan memahami inti nilai budaya Jawa dalam hal dagang.Melalui analisa hasil penelitian dan pemahaman para ahli

\footnotetext{
${ }^{5}$ Hasja W.Bachtiar,'The Religion of Java Commentary", dalam: Indonesian Journal of Cultural Studies, No,1, Vol.V, Januari 1973, hlm. 90.

${ }^{6}$ Hans Antlov dan Sven Cederoth (ed.), Kepemimpinan Jawa: Perintah Halus Pemerintahan Otoriter, (Jakarta: YIO), 2001, hlm. 19.

${ }^{7}$ Mochtar Pabottinggi,'Kebudayaan dan Otosentrisitas” dala: Agus R. Sarjono (ed.), Pembebasan BudayaBudaya Kita, (Jakarta: Gramedia, 1977), hlm. 138

${ }^{8}$ Francois Raillon,’Dapatkah Orang Jawa Menjalankan Bisnis ? Bangkitnya Kapitalis Pribumi di Indonesia", dalam: Hans Antlov dan Sven Cederroth (ed.), op. cit., hlm. 223-224.
} 
diharapkandapatmenjawab benar atau tidak dugaan negatif para cendikiawan tersebut. Sehinggadiharapkan dapat menjadi tantangan tujuan yangkeduaadalah, sebagai acuan peningkatan perekonomian baik di tingkat Regional (Jawa Tengah) maupun Nasional (Indonesia).

Sebenarnya, aktivitas perdagangan dalam kebudayaan Jawa pernah intensif terutama di wilayah pesisir utara Jawa, hubungan perdagangannya telah berlangsung berabad-abad lamanya. Di daerah Jawa dengan pengaruh Islamnya yang khas, misalnya kebudayaan pesisir dan daerah-daerah Jawa pedalaman, keduanya sering disebut sebagai daerah kejawen. ${ }^{9}$ Kejawen merupakan cap deskriptif bagi unsur-unsur kebudayaan Jawa dan bukan kategori keagamaan. Melainkan menunjukkan suatu etika dan atau gaya hidup dengan karakteristik pemikiran yang sinkretis dan toleran merupakan dasar bersedia menerima masukan dari berbagai agama formal yang bersama-sama mewujudkan kesatuan duniakehidupan Jawa. ${ }^{10}$

Aktivitas dagang orang Jawa pernah diseminarkan di Yogyakarta pada tahun 1990 disimpulkan, dalam budaya Jawa tidak ada sama sekali yang menentang dan merendahkan keberhasilan hidup seseorang melalui perdagangan. Kesimpulan lainnya,cara meningkatkan usahawan Jawa yang berhasil salah satunya adalah, dengan mengkaji ulang atau memahami kembali adat-istiadat atau tradisi dagang yang pernah dilakukan oleh para priyayi. ${ }^{11}$ Patokan penting identifikasi seseorang priyayi adalah kedinasannya dalam kerajaan. ${ }^{12}$ Adat-istiadat secara keseluruhan mengandung moralitas dari suatu komunitas sosial yang sering juga disebut "etos" merupakan sikap manusia berkenaan dengan hukum moral berdasarkan keputusan bebasnya. Etos kadang diartikan sebagai karakter tertentu, yaitu yang didasarkan pada unggulnya suatu nilai khusus, atau unggulnya sikap moral dari suatu nilai khusus seluruh bangsa atau sekelompok sosial. ${ }^{13}$

\footnotetext{
${ }^{9}$ Kodiran, "Kebudayaan Jawa" dalam: Koentjaraningrat ((ed.), Anthropology in Indonesian A Bibliograpical Review, ('s-Gravenhage: Martinus Nijhoff), 1995, hlm. 322.

${ }^{10}$ Niels Mulder, Mistisisme Jawa Ideologi Indonesia, (Yogyakarta: Lkis), 2001, hlm. 17.

${ }^{11}$ Francois Raillon,'Dapatkah Orang Jawa...."'<op. cit., 232-233. hlm. 110.

${ }^{12}$ Soemarsaid Moertono, Negara dan Usaha Bina Negara di Jawa pada Masa Lampau, (Jakarta: YOI), 1985,

${ }^{13}$ Lorens Bagus, Kamus Filsafat, (Jakarta: Gramedia), 2002, hlm. 672-673.
} 
Mencermati berbagai uraian permasalahan dagang Jawa sebagai satu kesatuan etosnya tersebut, makaistilah "dagang" dimaksudkan artinya tidak hanya dalam pengertian transaksi jual beli saja. Melainkan "dagang” dalam artinya yang lebih luas sebagaimana bisnis, usaha komersial maupun dalam ekonomi. Menurut Magnis Suseno, etos dagang orang Jawa (Indonesia) tidak berarti harus sebagai hybrid (perkawinan) dari etika tradisional dengan etika modern. Etos dagang Jawaharus modern seratus persen maksudnya, harus ditetapkan berdasarkan latarbelakang masyarakat Jawa. Karenanya, etos dagang Jawa mesti mencerminkan karakteristik budaya, peradaban, nilai-nilai, ciri keagamaan, pandangan dunia dan hidup orang Jawa. ${ }^{14}$ Mencermati penjelasan tersbut, maka dagangdi sini pengertiannya mengacu pendapat Mubyarto tentang sistem ekonomi Indonesia.Menurutnya sistem ekonomi Indonesia yaitu sistem ekonomi yang merupakan usaha bersama yang berasaskan kekeluargaan dan kegotongroyongan nasional atau sebagai ekonomi yang dijiwai oleh ideologi Pancasila juga disebut sistem ekonomi Pancasila. Sistem itu memiliki nilai moral sebagai dasar semangat jiwanya para pendukung dan inti sistem yang mengatur pola pikir dan bertindak para pelaku ekonominya. ${ }^{15}$

Bukan dimaksud di sini akan menganalisa realisasi etos sistem ekonomi Pancasila yang pernah dipraktekkan oleh priyayi seperti disimpulkan di sebuah seminar di muka. Melainkan, pengertian tersebut sebagai acuan analisa dan pemahaman yang walaupun, di satu pihak dianggap berbeda dengan caranya orang Barat berdagang. Namun pada pihak lain, pada kenyataannya masyarakat Jawa (priyayi) pernah meraih keberhasilan dalam hal dagang.Salah satu contohnya adalah, pada masa pemerintahan raja Mangkunegara IV di kerajaan Mangkunegaran (termasuk salah satu kerajaan Islam di Jawa) berhasil meraih berbagai kemajuan terutama di bidang perekonomian. ${ }^{16}$ Raja Mangkunegara IV (raja Islam Jawa)merupakan peletak dasar ekonomi perkebunan modern di Jawa pada masanya. ${ }^{17}$ Penjelasan tersebut menunjukkanbetapa pentingnya mengkaji kembali karakteristik etos dagang orang Islam Jawa agar dapat dijadikan sebagai bukti atau jawaban

\footnotetext{
${ }^{14}$ Franz Magnis Suseno, Berfilsafat dari Konteks, (Jakarta: Gramedia, 1992), hlm. 165-166.

${ }^{15}$ Mubyarto, Ekonomi Pancasila, (Jakarta: LP3S, 1993), hlm. 27.

${ }^{16}$ Th.G.Th.Pegeaud, Pangeran Adipati Ario Mangkunegoro IV sebagai Pujangga, terj.R.T.Muhammad Husodo Pringgokusumo, (Surakarta: Rekso Pustoko Istama Mangkunegaran, 1987), hlm. 3.

${ }^{17}$ Pringgodigdo, Sejarah Perusahaan-Perusahaan Kerajaan Mangkunegaran, terj, R.T.Muhammad usodo Pringgokusumo, (Surakarta: Rekso Pustoko Istana Mangkunegaran, 1986), hlm. 47.
} 
atas dugaan negatif para cendikiwan terhadap etos dagang orang Islam Jawa seperti tersebut di muka.

Mencermati penjelasan keberhasilan orang Islam Jawa tersebut, maka jenis penelitian di tulisan ini adalah penelitian kepustakaan (library research).Karenanya, analisa yang dipergunakan yaitu analisa isi (content analysis) ${ }^{18}$ dipadukan dengan pendekatan hermeneutic ${ }^{19}$ juga menggunakan metode verstehen ${ }^{20}$ sebagaimana diterapkan dalam hermeneutic ilmiah. ${ }^{21}$ Penerapan metode itu bertujuan untuk menganalisa dan memahami makna murni $^{22}$ berbagai karya raja Mangkunegara IV sebagai salah satu acuan pemikiran etos dagang orang Islam yang sesuai pada masanya. Agar pemahamannya juga bisa sebagai acuan etos dagang orang Islam Jawa sekarang dan masa depan, maka diperlukan analisis dengan pendekatan sosiologis, ${ }^{23}$ dengan modelnya bersifat interpretasi sosiologik ${ }^{24}$ Melalui berbagai langkah tersebut diharapkan dapat menghasilkan konstruksi teoritis pemahaman etos dagang orang Islam Jawa analisa pemahamannya untuk sementara pada tulisan ini dibatasi tiga hal. Pertama, karakteristik budaya Jawa sebagai dunia kehidupan etos dagang

\footnotetext{
${ }^{18}$ Analisa isi (content analysis) adalah, teknik penelitian untuk membuat inferesi-inferesi yang dapat ditiru (replicable) dan sahih data dan dengan memperhatikan konteksnya.Analisis isi dapat dikararakterisasikan sebagai metode makna simbolik pesan-pesan. Klaus Krippendorff, Analisis Isi: Pengantar Teori dan Metodologi, terj. Farid Wajdi, (Jakarta: P.T.Raja Grafindo, 1993), hlm. 15.

${ }^{19}$ Secara bahasa kata hermeneutic berasal dari kata kerja Yunani hermeneuin artinya "menafsirkan" (to interpret) dan menafsirkan itu sendiri merupakan gabungan dari pernyataan "menerangkan" dan "menerjemahkan".Penekanannya adalah pada aktifitas interpretasi, terutama teks. Joshep Bleicher. Contemporary Hermeneutics:: Hermenuetic is Method, Philosophy and Critique, (London: Routledge and Poul Kegan, 1980), hlm.. 3-5.

${ }^{20}$ Metode verstehen adalah, upaya memahami secara kejiwaan kelakuan orang lain serta karya ciptanya, yakni upaya interpretative untuk memberikan makna kepada sesuatu yang dianggap pada hakikatnya bersifat "fakta obyektif”. Iman Suproyogo, dan Tobroni, Metodologi Penelitian Sosial Agama, (Bandung: PT Remaja Rosdakarya, 2001), hlm. 71.

${ }^{21}$ Hermeneutik Ilmiah yaitu, kecenderungan menggunakan hermeneutic khusus untuk mengungkapkan dan mempelajari makna "murni" yang terkandung dalam sebuah teks.Tujuannya adalah untuk mengembangkan pengetahuan yang memberikan penjelasan dan pemahaman yang menyeluruh dan mendalam.Ibid., hlm. 73-75.

${ }^{22}$ Maksudnya murni di sini, sebagaimana saran Van Leur, bahwa untuk menentukan makna moral perdagangan bagi 'sejarah lama Indonesia' metode kajiannya hendaknya berlandaskan pada "elemen yang lebih tua, yang asli atau murni (native)", misalnya unsure kejawaan adalah factor yang paling penting. R.Z.Leirissa, "DR J.C. Van Leur dan sejarah Ekonomi: Suatu Tinjauan Historigrafi”, dalam: Taufik Abdullah (peny.), Sejarah Indonesia Penilaian Kembali Karya Umum Sejarawan Asing, (Jakarta: PPKBLP UI, 1997), hlm. 197.

${ }^{23}$ Dengan pendekatan sosiologis terungkap segi-segi sosial dan peristiwa yang dikaji.Pembahasannya mencakup golongan social yang berperan, jenis hgubungan social, konflik berdasarkan kepentingan, pelapisan social, peran dan status social dan sebagainya. Dudung Abdurrahman, Metode Penelitian Sejarah, (Jakarta: Logos Wacana Ilmu, 1999), hlm. 11.

${ }^{24}$ Interpretasi Sosiologik adalah, melakukan penafsiran dengan tetap berpegang pada materi yang ada, dicari latarbelakangnya, konteksnya agar dapat ditemukan konsep atau gagasannya lebih jelas. Dengan demikian dapat terungkap makna atau nilai logis, etik serta nilai transendentalnya, apa maknanya, apa keberartiannya bagi hidup manusia. Imam Suprayogo dan Tobroni, Metodologi..., op. cit., hlm. 138.
} 
orang Islam Jawa.Kedua, salah satu contoh implementasi pemikiran etos dagangnya.Keduanya merupakan kesatuan pemahaman dan yang ketiga,agar nilai keunggulan atau nilai kekhususan etos dagangnya dapat dipahami atau menjadi acuan kontruksi teoritis, maka perlu dibandingkan dengan budaya dagangnya etnis Cina yang uraian bahasannya masing-masing sebagai berikut.

\section{B. Pembahasan}

\section{Budaya Jawa dalam Dunia Kehidupan Etos Dagang Orang Islam Jawa}

Menurut C. Gertz, kebudayaan adalah susunan dinamisnya ide-ide dan aktivitasaktivitas yang saling berhubungan dan saling mempenguruhi satu sama lainnya secara terus menerus. ${ }^{25}$ Van Peursen menjelaskan, kebudayaan pada dasarnya merupakan endapan dari kegiatan serta karya manusia. Hakikat kebudayaan sama dengan hakikat manusia yang, jika ditulis dalam buku, tidak akan ada habis-habisnya. ${ }^{26}$ Walaupun demikian, tentangbudaya Jawa Gunawan S. menjelaskan, para ahli kebudayaan baik dari luar negeri maupun yang ada di dalam negeri, pada prinsipnya mereka memiliki kesamaan dalam memandang central concepts nilai-nilai moral budaya Jawa "yang diidealkan' atau budaya Jawa yang dipikirkan terutama daerah Solo dan Yogyakarta.Kesamaan pandangannya itu bisa ditarik sebagai konsep inti budaya Jawapada umumya mengandung tiga karakteristik.Pertama, budaya Jawa mendasarkan diri kepada yang harmonis.Biasanya disebutkan bahwa, budaya Jawa adalah anti konflik karena di dalamnya memiliki tujuan ideal yaitu, dunia ini harus ditata secara harmonis baik antara jagad cilik (jiwa, pikiran, hati nurani manusia) maupun denganjagad gede (komunitas, masyarakat).Cara-caranya untuk menjaga atau menuju kehidupan harmonis adalah, terutama dengan sikap toleransi. Budaya Jawa adalah budaya yang paling memberi tempat bagi perbedaan dan menerima perbedaan sebagai kekayaan yang harus dipupuk bersama.

Kedua, budaya Jawa dalam konteks modern lebih sesuai dengan paradigm struktural fungsional, dengan asumsi bahwa setiap orang atau lembaga memiliki tempat

\footnotetext{
${ }^{25}$ Clifford Gertz,"The Impact of the Concept of Cultur on the Concept of Man", dalam: John R. Platt (ed.), New Views of the Nature of Man, (Chicago: The University of Chicago Press, 1965), hlm. 93.

${ }^{26}$ C.A Van Peursen, Strategi Kebudayaan, terj. Dick Hartoko, (Yogyakarta: Kanisius, 1976), hlm. 9.
} 
masing-masing. Ia harus berperilaku atau bekerja sesuai dengan tempat keberadaannya tersebut. Pemahaman tentang "tempat" bukan pemahaman mati atau mutlak, namun sebagai sesuatu yang kondisional dan relatif.Ketiga, budaya Jawa menghargai berbagai hal atau nilai-nilai yang bersifat transendental. Maksudnya, sesuatu yang berhubungan dengan yang transendental, yang bukan dunia material, tetapi sebagaimana dalam filsafat yaitu, sesuatu yang Metafisis atau Numinus (Yang Ilahi). Nilai transendental ini terutama termuat dalam apa yang disebut sebagai kejawen (mistik Jawa) yang dalam sastra disebut suluk, wirid, primbon, serat atau istilah lain yang sejenis. Sifat transendental itu dilatarbelakangi keyakinan: hidup selalu bergantung kepada Tuhan Yang Maha Kuasa. ${ }^{27}$

Mencermati berbagai uraian tentang budaya Jawa tersebut dapat dijadikan acuan etosnya para pedagang atau sebagai etos dagang orang Jawa, makadisatu pihak ditetapkan baik berdasar padadunia kehidupan maupun di pihak lainnya,disesuaikan dengan sikap moral dan sikap batin yang sudah terbiasa. Dimaksud terbiasa yaitu, sikap batinnyaatau etosnya selalu dilatarbelakangi oleh peradaban, nilai-nilai, ciri keagamaan,pandangan dunia masyarakat Jawa sesuai pada masanya.Magnis Suseno menjelaskan, dunia kehidupan merupakan konteks bersama sekelompok orang terdapat cakrawala pengetahuan-pengetahuan, nilai-nilai dan norma-norma yang bagi para ahli sebagai barang tentu, yang tidak direfleksikan dan merupakan latar belakang pendapat dan penilaian-penilaian untuk dipersoalkan sesuatunya.Dunia kehidupan sebagaitandonanggapan-anggapan, latarbelakang yang diorganisasikan dalam bahasa, yang mereproduksikan diri dalam bentuk tradisi kultural dan berfungsi sebagai konteks komunikasi. Ia sebagaitandon pengetahuan dan anggapan yang perlu diandaikan untuk mengambil sikap. ${ }^{28}$

Mengenai etos Magnis Suseno lebih menjelaskan, terdapat kesamaan antara sikap moral dengan etos tetapi tidak identik.Kesamaannya terletak pada kemutlakan sikapnya, sedang perbedaannya terletak pada tekanannya.Sikap moral, menegaskan orientasi kepada norma-norma sebagai suatu standar yang harus diikutinya sementara etos

\footnotetext{
${ }^{27}$ Gunawan Sumodiningrat,'Budaya Jawa dan Integrasi Nasional”, dalam: Laila Ratna Kumala (ed.)Keraton Surakarta dan Perubahan Masyarakat: Membumikan Nilai-Nilai Tradisional, (Surakarta: Team Simposium Nasional, 2003), hlm. 8.

${ }^{28}$ Franz Magnis Suseno, 12 Tokoh Etika Abad Ke 20, (Yogyakarta: Kanisius, 2000), hlm. 223.
} 
menegaskan bahwa sikap tersebut merupakan sikap yang sudah mantap dan sudah menjadi kebiasaan, suatu yang sudah nyata-nyata mempengaruhi, dan menentukan bagaimana seseorang atau sekelompok orang mendekati dan melakukan sesuatu pekerjaan. Karenanya, istilah etos diungkapkan sebagai semangat batinnya seseorang atau sikap batin yang tetap pada seseorang (sekelompok orang) sejauh didalamnya termuat tekanan-tekanan moral atau nilai-nilai moral tertentu. ${ }^{29}$

Menurut K. Bertens, etos termasuk salah satu kata Yunani yang masuk ke dalam banyak bahasa (termasuk di bahasa Indonesia). Kata tersebut menunjukkan ciri-ciri, pandangan, nilai-nilai yang menandai suatu kelompok atau seseorang. Dijelaskan, dalam Concise Oxford Dictionary (1974), kata etos disifatkan sebagai characteristic spirit of community people or system.Maksudnya, etos adalah suasana khas yang menandai suatu kelompok, seseorang atau sistem. Etos menunjukkan pada suasana khas yang meliputi kerja atau profesi, dan perlu ditekankan bahwa, kata "suasana" harus dipahami dalam arti baik secara moral. Karenanya, jika bicara etos dalam profesi tertentu, mesti sebagai hal baik atau yang terpuji. ${ }^{30}$ Itulah sebabnya, misalnya sikap komersial pedagang sebagai profesinya, tentu etos dagangnya cenderung kurang baik jika satu-satunya tujuan bisnis adalah maksimalisasi keuntungan kepada yang hanya berupa uang.

Mencermati penjelasan tentang etos tersebut di atas maka, dalam kata etos mengandung dua nilai sebagai satu kesatuan kebaikan tindakan yang selalu dilakukan atau sebagai tindakan terpuji yang sering dilakukan pada bidang profesi tertentu. Pertama, orientasi nilai-nilai moral sebagai dasar sikap moral seseorang dalam bersikap dan bertindak sebagai bagian profesinya dan dapat menjadi standar yang sebaiknya atau seharusnya diikuti oleh orang dan masyarakat sesuai pada masanya.Kedua, bukti praktiknya dan cara pelaksanaannya tentang hal itu. Eksistensi nilai-nilai moral sebagai dasar sikap moralnya tindakan terpuji ini berarti, di satu pihak berada pada dataran pikiran atau konsep serta dihayati pelaksanaannya dalam kehidupan terutama dalam hal ini di bidang dagang pada pihak lainnya.

\footnotetext{
${ }^{29}$ Franz Magnis Suseno, Berfilsafat Dar..., op. cit., hlm. 120.

${ }^{30}$ K. Berten, Etika, (Jakarta: Gramedia, 2005), hlm. 225-226.
} 
Berdasarkan pada penjelasan tersebut, maka untuk memahami rincian kebaikan nilai-nilai moral etos dagang orang Islam Jawa, juga diperlukan dua petunjuk penting lainnya. Pertama, perlu analisa pemahaman terhadap berbagai ungkapan Jawasebagai bagian budaya dalam dunia kehidupannya baik dengan pemahaman-pemahamannya maupun caranya bersikap atau bertindak terutama di bidang dagang.Kedua, perlu bukti konsep pemikiran nilai-nilai moralJawa dengan pemahaman caranya bersikap sebagai pelaksanaan etos dagangnya, pernah berhasil dipraktikkan oleh para priyayi dahulu salah satunya yaitu raja Mangkunegara IV pada masa pemerintahannya di kerajaan Mangkunegaran. Pringgodigdo menjelaskan, sehingga waktu itu pemerintahannya disebutKala Sumbaga maksudnya, masa yang sangat sejahtera. ${ }^{31}$. Abdullah menjelaskan, raja Mangkunegara IV temasuk salah seorang filsuf dunia dari Indonesia tercatat dalam Dictionnaire des Philosophes. ${ }^{32}$ Karenanya, berbagai pemikiran seperti yang tertulis dalam karya-karyanya mengandung nilai-nilai moral yang dapat dijadikan sebagai acuan etos dagang orang Islam Jawa.

Dua petunjuk penting tersebut merupakan satu kesatuan ungkapan baik tentang kebaikan nilai-nilai moralnya maupun cara bersikap sebagai implementasi etos dagangnya.Terdapat berbagai macam ungkapan Jawa dengan nilai-nilai moralnyamemerlukan analisa pembahasan yang luas dan panjang. Karenanya,dalam tulisan ini untuk sementara hanya akan diuraikan bahasannnya terhadap ungkapanungkapan Jawa yang terkait dengan masalah perdagangan.Misalnya, dalam dunia kehidupan Jawa ada ungkapan: Timun wungkuk jaga imbuh.Artinya,timunyang bengkok disiapkan untuk tambahan gratis bagi konsumen, maksud maknanya adatiga.Pertama,timun bengkok sebagai simbol barang dagangan yang cacat, tidak berdaya jual beli, atau sebagai barang yang tidak berguna atau remeh. Bagi pedagang Jawa dagangan yang cacat bukan ditutupi atau dicampur dengan yang baik, karena ituakan mengecewakan atau membohongi konsumen. Kedua, barang-barangyang sering dianggap tidak ada hubungan dengan dagangan atau hal-hal yang tidak berdaya jual beli sering dianggap tidak berguna atau remeh seperti, kebersihan dan keindahan lingkungan, cara bicara dan berbagai tingkah laku ketika melayani konsumen. Semua itu tetap dijaga

\footnotetext{
${ }^{31}$ Pringgodigdo, Sejarah Perusahaan-Perusahaan Kerajaan...., op [, cit., hlm. 48

${ }^{32}$ Abdullah Ciptoprawiro, Filsafat Jawa, (Jakarta: Balai Pustaka, 2000), hlm. 52.
} 
dengan sebaik-baiknya sebagai ungkapan sikap baik atau hormat (sopan santun) pedagang Jawa baik kepada apa saja (lingkungan) maupun kepada sesama (konsumen). Ketiga, makna pertama dan kedua itu bagi etos dagang orang Jawa, tidak dihitung dengan memasukkan harga tambahan pada barang dagangan, walaupun diakuinya itu termasuk rugi. Namun, kebaikan sikap-sikap tersebut diyakini dapat menjadi "iklan jalan" maka akan menambah pelanggan atau persaudaraan yang juga meningkatkan sikap gotongroyong dalam berbagai bidang kehidupan sosialnya. Karenanya, berdasarkan pada tiga makna tersebut dalam dunia kehidupan etos dagang orang Islam Jawa terkait erat dengan ungkapantuna saktak bathi sanak maksudnya, biarlah rugi sedikit (seukuran tertentu:misalanya jerih payah) tetapi pasti mendapat laba persaudaraan atau sebagai pelanggan. $^{33}$

Rincian nilai-nilai moral dengan contoh cara bersikap dalam dunia kehidupan etos dagang orang Jawa sebagai implementasi dua ungkapan tersebut,melalui tujuh sikap sebagai berikut.Pertama, bermuka manis dan bermata lembut atau susila bertingkahlaku serta menghindarkan kecurigaan. Kedua, berbicara halusatau melalui berkata-kata yang enak didengar.Ketiga, ramah-tamah atau bersikapetis yaitu perilaku yang memperlihatkan keakraban.Keempat, pandai membawakan diri agar menyesuaikannya dengan adatistiadat masyarakat luas.Kelima merendah diri (andhapasor) mesti berpangkat tinggi.Keenam, bicara yang bermanfaat atau jika tidak dapat maka lebih baik diam dan ketujuh,sederhana atau wajar (prasojo) maksudnya dalam bertingkahlaku tidak dibuatbuat.Rincian berbagai perilaku etis tersebut berdasarkan pada pemikiran raja Mangkunegara IV yang diungkapkan dalam karyanya Serat Darmalaksita sebagai berikut:

"Rambah malih wasitaning siwi, wikanana patraping agesang, kang kanggo salawase, manising netra ruruh, angedohken mring salah tampi, wong kang trep sileng tata, tan agawe rengu, wicara lus kang mardawa, iku datan kasendu marang sasami, wong kang rumaket ika. Karya resep mring rewange linggih, wong kang manut mring caraning bangsa, watek jembar pasabane, wong andhap asor iku, yekti oleh panganggep becik,

\footnotetext{
${ }^{33}$ Yacob Oetomo, Dunia Usaha dan Etika Bisnis Jawa, (Jakarta: Kompas, 2001), hlm. 28.
} 
wong meneng iku nyata, neng jaban pakewuh, wong prasojo solahora, iku ora gawe ewo kang ningali, wong nganggo tepaniro”

Terjemahannya: "Tambah lagi beberapa petunjuk untuk anak, ketahuilah tatakrama pergaulan hidup yang hendak dipakai selama-lamanya, bahwa manis dan lembutnya pandangan mata, menjauhkan kesalahpahaman orang-orang yang menerapkan tata susila tidak diragukan orang, bicara halus dan sedap didengar, tidak bakal diungkat orang, yang menunjukkan keakraban itu menyenangkan orang. Yakni membuat senang temannya semajlis orang yang bisa mengikuti adat tata cara suatu bangsa, ia berwatak luas pandangannya dan jauh jelajahi negeri yang ia kunjungi, orang yang merendahkan diri (rendah hati) niscaya ia dipandang orng baik budi, orang yang bersifat pendiam apabila ia tidak dapat berbicara tentang sesuatu yang berguna adalah lebih baik dan slamat dari bencana lidah, orang yang berperilaku sederhana dan wajar tidak membuat orang dengki dan antipasti, bahkan perilakumu dijadikan teladan bagi orang lain. ${ }^{34}$

Rincian tujuh nilai moral dengan contoh caranya bersikap bagi etos dagang orang Islam Jawa tersebut merupakan acuan penting bagi dunia kehidupan Jawa. Acuan pentingnya yaitu, pada nilai-nilai moral tersebut terkandung kesadaran bahwa, manusia hendaknya selalu bersikaptahu diri sama denganeling. Sebab,jagad ora sagodhong kelorartinya, dunia tidakhanya sebesar daun kelor. Karenanya, pedagang hendaknyajuga mampu bersikap pinter ojo kuminter, sugih ojo semugih artinya, kepandaian dan atau kekayaan sebaiknya jangan dipamer-pamerkan. Makna etisnya dua ungkapan tersebut di satupihak terkait dengan sikap eling juga mengimplikasikan sikap nrima pada pihak lainnya. Kedua sikap batin itu mengandung maksud bahwa, pedagang dalam keadaan kecewa atau dalam kesulitan-pun hendaknya bereaksi dengan rasional, dengan tidak putus asa dan juga dengan tidak menentang secara percuma. Pedagang dengan sikap itu suatu malapetaka kehilangan rasa sengsaranya sebagaimana terungkap pada kata-kata Jawa: bungah sajroning susah, prihatin sajroning bungah artinya, ia tetap gembira dalam penderitaan dan prihatin dalam kegembiraan. Oleh karena itu, pedagang hendaknya memiliki semangat batin ojo leren lamun durung sayah, ojo mangan lamun durung luwe

\footnotetext{
${ }^{34}$ Sri Mangkunegara IV,"Serat Darmalaksita", dalam: Ki Padmasusastra, Dwidja Isjwara, (Surakarta: Abert Rusche\& Co., 1889), hlm. 98-99.
} 
maksudnya, jangan berhenti bekerja sebelum capai, jangan makan sebelum lapar. Duasikap batin tersebut memiliki alasan kesadaran mendalam, karena wong urip ora gampang, diarani gampang yo gampang, diarani angel yo angel artinya, hidup itu tidak mudah, disebut mudah ya mudah, disebut sulit ya sulit. ${ }^{35}$

Menurut raja Mangkunegara IV, acuan nilai-nilai moral dengan contoh caranya bersikap dalam dunia kehidupan etos dagang orang Islam Jawa sebagai implementasi berbagai ungkapan Jawa tersebut di atas adalah, pedagang hendaklah ber-etos denganlima sifat dan delapan macam cara bersikap etis yang berguna (Asta Gina). Etos lima sifat ini adalah, rajin (sregep), bersungguh-sungguh (pethel), tabah-hati (tegen), tekun (wekel), berhati-hati (pangati-ati). ${ }^{36}$ Maksudnya Asta Gina yaitu pertama, membudidayakan berbagai bidang usaha sebatas kemampuan maksimal sesuai dengan kondisi jamannya (panggautan gelaring pambudi). Kedua, pandai mencari jalan keluar untuk memperoleh sesuatu yang diinginkan (rigen), yang ketiganya, hemat dan hati-hati membelanjakan atau menggunakan penghasilan (gemi), Keempat, teliti dan cermat dalam memeriksa pekerjaan agar mendapatkan sesuatu yang pasti dengan tidak meraba-raba (nastiti) demi langkahlangkah selanjutnya. Kelima, memahami perhitungan biaya, merencanakan belanja terutama tentang berapa besar biaya hidup yang diperlukan (wruh ing petungan). Keenam, rajin bertanya kepada para ahli menurut ilmunya masing-masing dengan tidak malu-malu untuk menambahah pengetahuan dan atau ketrampilan (taberi tatanya). Ketujuh, mencegah atau menahan kehendak hawa nafsu dari berbagai keinginan yang tidak berfaedah serta menjauhi pemborosan (nyegah kayun pepinginan.....tan boros marang arto). Kedelapan, bertekad bulat atau berniat yang teguh. Sikap demikian itu akan dapat berpengaruh bagi tercapainya berbagai cita-cita dalam waktu yang tidak lama (nemen ing seja, watekira sarwa gelis ingkang kinapti). ${ }^{37}$.

Bersikap sopan santun atau ramah tamah memang berperan penting, namun setiap stakeholders hendaknya bisa bersikap tahu diri (eling) secara wajar (prasojo). Caranya adalah, selalu waspada atau berhati-hati baik dalam bicara maupun bersikap dengan

\footnotetext{
${ }^{35}$ Bdk. Soetrisno, Falsafah Hidup Pancasila Sebagaimana Tercermin dalam Falsafah Hidup Orang Jawa, (Yogyakarta: Pandawa, 1977), hlm. 21-26.

${ }^{36}$ Sri Mangkunegara IV,"Serat Darmalaksita”, dalam: Ki Padmasusastra, Dwidja ..., op.,cit., hlm. 96.

${ }^{37}$ Ibid., hlm. 93.
} 
mempertimbangkan situasi dan atau kondisi lingkungan. Acuan teknisnya yaitu, dengan selalu menyesuaikan diri terhadap dimaksudkalimat-kalimat: ngono yo ngono, ning ojo ngono artinya, barangkali engkau betul, tetapi jangan memakai cara seperti itu. Sebab, becik ketitik ala ketara maksudnya, yang baik akan nampak dan yangjelekpun akan kelihatan. ${ }^{38}$ Magnis Suseno menjelaskan, setiapstakeholdersdapat bersikap eling secara wajar (prasojo) jika masing-masing dirinya selalu melakukan prosesdialogis partisipasi pada kesadaran transendental. Maksudnya adalah, proses komunikasi antar semua pihak yang berkepentingan (stakeholder SDA dan SDM) terjalin dalam dalam suatu dialogis yang bebas dari kekuasaan. Terwujudnya proses komunikasi itu merupakan kepentingan transendental manusia. Maksudnya adalah, seperti ketika para pedagang, manajer, karyawan, pemasok, pelanggan, konsumen, dan lingkungan masyarakat, atau sang tuan dengan si budak suatu saat secara bersama-sama memikirkan pemecahan sebuah masalah, mereka bukan lagi seperti tuan dan budak melainkan sam-sama sebagai sesama manusia. $^{39}$

Magnis Suseno menjelaskan, dalam proses dialogis partisipatif pada kesadaran transendental inimengandung tiga sikap adalah,eling (tahu diri), aja mitunani wong liya,dan bersikap ngemong,maknanya sama dengan bersikap integrasi. Ketiga sikap tersebut juga sebagai satu kesatuannya sikap sepi ing pamrih. Penjelasan dimaksud berbagai sikap tersebut yaitu, hendaknya kita jangan melakukan sesuatu demi kepentingan diri kita sendiri yang dapat mengganggu atau merugikan lingkungan, membahayakan orang lain dan mengurangi kualitas hidup generasi-generasi yang akan datang. Karenanya, kita harus sepi ing pamrih artinya, kita hendaknya bersedia untuk tidak mementingkan kepentingan individual kita tanpa peduli terhadap sesame.Kepentingan kita diakui, tetapi jangan dikejar secara eksklusif.Usaha agar kita dapat sepi ing pamrih, kita harus bersikap tahu diri (eling).Eling berarti, kita jangan menganggap diri sebagai pusat dunia, sebagai satu-satunya yang penting.Bersikap eling artinya, ingat, siapa kita, bahwa kita berasal dari orang lain, merupakan anugerah Tuhan bahwa kita hidup dari masyarakat dan dari alam, dan oleh karena itu jangan pernah

\footnotetext{
${ }^{38}$ Yacob Oetomo, Dunia Usaha..., op. cit., hlm. 25.

${ }^{39}$ Franz Magnis Suseno, Pijar-Pijar Filsafat dari Gatholoco ke Filsafat Perempuan dari Adam Muller ke Postmodernisme, (Yogyakarta: Kanisius, 2005, hlm. 158.
} 
memperalat mereka demi kepentingan kita sendiri. Orang akan tahu diri apabila ia eling atau ingat. Jika orang memiliki sikap-sikap itu akan sanggup menjalin hubungan serasi dengan alam sekeliling yang kebaikan moralnya yaitu, kita jangan mencari kemenangan, sama dengan bermaksudaja mitunani wong liya (jangan merugikan orang lain). Melainkan, demi keseimbangan lingkungan kehidupan. ${ }^{40}$

Aja mitunani wong liya merupakan norma moral terpenting atau prinsip dasar etika sosial Jawa. K. Bertens lebih menjelaskan, jangan merugikan orang lain itu termasuk dasar sikap baik yang hakiki atau terpenting dalam dagang. Maksudnya, janganlah dagang sampai menjadi pekerjaan kotor. Karenanya, dalam dagang harus disertai dengan sikap tahu diri (bhs Jawa: eling), sehingga sudah semestinya memperhatikan rambu-rambu moral sebagaimanateori perhatian semestinya (the due care theory). Kata "perhatian" harus dipahami sebagai perhatian efektif yang bersedia mengambil tindakan seperlunya. Norma dasar yang melandasi teori perhatian semestinya adalah, seseorang tidak boleh atau jangan merugikan orang lain dalam kegiatannya. Teori tersebut tidak memfokuskan pada kontrak sosialnya dalam persetujuan antara konsumen dan prodosen saja, melainkan terutama kualitas produk serta tanggung jawab prodosen atau pedagang. Karenanya, tekanannya bukan hanya pada hak legal atau hukum saja, melainkan pada etika dalam arti luas. Motto yang berlaku pada teori perhatian semestinya bukancaveat emptor ("hendaklah si pembeli hati-hati") saja, melainkan juga caveat venditor ("hendaklah si penjual hati-hati"). Norma dasar "tidak merugikan"ini dapat diterima atau memiliki kesesuaian baik dengan teori etika deontologi maupun utilitarianisme,teori hak, juga dalam teori keadilan, makanya teori perhatian semestinya memiliki basis etika yang teguh. ${ }^{41}$ Orang dapat memiliki kekuatan moral aja mitunani wong liya (jangan merugikan orang lain) dalam dagang,jika memiliki sikap integrasi artinya, bersedia bersikap terbuka keluar. Maksudnya, bersedia bersikap hormat atau bersikap baik terhadap aneka tradisi atau budaya, pandangan hidup atau agama yang berbeda bagi setiap orang yang hidup bersama dalam masyarakatnya demi tercipta suasana yang tenang, gembira, bebas dari rasa takut dan bebas dari rasa tekanan. ${ }^{42}$

\footnotetext{
${ }^{40}$ Franz Magnis Suseno, Kuasa dan Moral, (Jakarta: PT SUN, 2001), hlm. 168.

${ }^{41}$ K.Berten, Pengantar Etika Bisnis, (Jakarta: Gramedia, 2000), hlm. 236-237.

${ }^{42}$ Franz Magnis Suseno, Kuasa dan...., op. cit., hlm. 97.
} 
Mencermati berbagai penjelasan implementasi nilai-nilai moral diberbagai sikap moralmelalui prosesdialogis partisipatif pada kesadaran transendental tersebut berarti,dalam dunia kehidupan etos dagangnya orang Jawa dituntut mampu mengendalikan berbagai keinginan hawa nafsunya. Menurut Magnis Suseno, yang dipandang sebagai hawa nafsu (nafsu jelek) dan berbahaya bagi orang Jawa hampir tidak berbeda dari pandangan orang Eropa Barat yang normal. Banyak dalam kepustakaan dan tradisi pendidikan Jawa didaftar nafsu-nafsu yang berbahaya, antara lain yang sangat populer disingkat "malima": main, madon, madat, minum,maling. ${ }^{43}$ Bahaya lainnya yang harus diperhatikan orang Jawa adalah pamrih. Bertindak yang berdasarkan pada pamrih berarti, hanya mengusahakan kepentingan diri sendiri saja dengan tidak menghiraukan kondisi dan berbagai kepentingan masyarakat. Pamrih kelihatan dalam tiga nafsu yaitu, nepsu menange dewe artinya, selalu mau menjadi orang yang pertama, nepsu benere dewe artinya, menganggap diri selalu betul dan, nepsu butuhe dewe maksudnya, hanya memperhatikan kebutuhannya sendiri. Orang yang dikuasai tiga nafsunya pamrih perilakunya cenderung menjadi adigang, adigung, adiguna maksudnya yaitu, dia suka memperlihatkan (pamer) kekuasaan, kekayaan dan, kekuatan (kesaktian). Perilaku orang dengan sifat-sifat disebut terakhir itu cenderung mudah menimbulkan berbagai sifat yang amat dibenci orang Jawa yaitu, dahwen dan open artinya, sering mencampuri urusan orang lain. Drengki sama dengan bersikap dengki artinya, tidak suka melihat orang lain sukses, srei atau suka iri, jail artinya, suka main intrik dan,methakil:suka bersikap kasar. ${ }^{44}$

Pedagang yang terus berusaha dan berhasil mengendalikan berbagai hawa nafsu tersebut di atas dapat memiliki etos dagang orang Islam Jawa yangsesuai, baik dengan dunia kehidupan maupun bagi kemajuan manusia di masanya. Maksudnya sesuai dengan dunia kehidupan dalam hal ini tiga, pertama etos dagangnya sesuai dengan karakteristik budaya Jawa: harmonis, struktural fungsional dan, transendental. Kedua, etosnya juga sesuai dengan nilai-nilai moral budaya Jawa dipraktikkkan melalui berusaha bersikap baik atau hormat dan rukun yang sesuaidengan tata krama Jawa di masanya.Kesesuaian tata karma Jawa yang diimplementasikan sebagai etos dagang orang Islam Jawa ada tiga. Pertama, bersikap baik atau hormat dan peduli terhadap apa saja, kedua, bersikap baik

\footnotetext{
${ }^{43}$ Ibid., hlm. 139.

${ }^{44}$ Soetrisno, Falsafah Hidup Pancasila..., op. cit., hlm. 22-28.
} 
atau hormat dan peduli serta rukun terhadap sesama manusia dan, ketiga, sesuai dengan budaya atau pengalaman keagamaan Islam Jawa. ${ }^{45}$

Rincian nilai-nila moral dengan contoh cara bersikap yang sesuai, baik dalam dunia kehidupan etos dagang orang Islam Jawa maupun dengan tata karma Jawa pada masanya, sebagaimana diungkap melalui berbagai kalimat Jawa. Seperti, timun wungkuk jaga imbuh. Tuna saktak bathi sanak dan lain sebagainya seperti telah dijelaskan di muka.Sedangkan yang sesuai dengan tata krama Jawa sebagaimana yang pernah dipraktikkan raja Mangkunegara IV dengan nilai-nilai moralnya yang diungkap di berbagai karya sastranya di muka. Inti terpenting tujuan tata krama Jawa melalui bersikap baik atau hormat dan rukunsebagai etos dagang orang Islam Jawa adalah,aja mitunani wong liya. Untuk itu pedagang dituntut bersikap eling (tahu diri) dan ngemong (integrasi).Acuan dasar ketiga sikap moral tersebut dapat dipraktikkan dalam duniakehidupan etos dagang orang Jawa, apabilaia memiliki semangat batin atau memiliki etossepi ing pamrih.

Menurut K. Bertens, sepi ing pamrih merupakan keutamaan moral atau etos Jawa yang belum muncul dalam cakrawala pandangan moral Aristoteles dan termasuk sebagai salah satu dari etos pokok yaitu, iman atau kepercayaan, pengharapan dan, cinta kasih atau tresno. ${ }^{46}$ Magnis Suseno menjelaskan, orang (pedagang) yang bertindak karena pamrih-nya sendiri sama dengan egoisme. Artinya, ia hanya mengusahakan kepentingan individualnya saja dengan tidak menghiraukan berbagai kepentingan masyarakat. Ia mencari berbagai kepentingan dalam dunia dan dengan demikian mengikat dirinya terhadap alam luar sehingga ia kehilangan kesanggupan untuk memusatkan kekuatan dalam batinnya sendiri (rasa-nya) menjadi dangkal atau mati. Manusia dapat dikatakan sepi ing pamrih apabila ia tidak lagi mengejar kepentingan-kepentingan individualnya (egonya) sendiri tanpa memperhatikan keselarasan sosial seluruhnya. Karenanya, ia yang sepi ing pamrih(bebas dari pamrih) akan mengembangkan sikap-sikap etis seperti, nrimo, ikhlas dan rila atau lila (legawa). ${ }^{47}$ Sikap moral yang sering diucapkan bersama dengan

\footnotetext{
${ }^{45}$ Lihat Daryono, Etos Dagang Orang Jawa Pengalaman Raja Mangkunegara IV, (Yogyakarta: Pustaka Pelajar, 2007), hlm. 200-263..

${ }^{46}$ K. Berten, Etika ...., op. cit., hlm. 222..

${ }^{47}$ Franz Magnis Suseno, Kuasa dan...., op. cit., hlm. 140-147.
} 
etossepi ing pamrih adalah rame ing gawe.Mulder menjelaskan, rame ing gawe artinya,setiap pihak hendaknya memenuhi kewajiban pada tempatnya masing-masing di mana kita harus berperan, entah sebagai petani, pedagang, abdi, pegawai atau sebagai raja(pajabat negara). ${ }^{48}$

Berbagai penjelasan tersebut mengimplikasikan maksud, pedagang bisa dikatakan telah memiliki etos dagang orang Islam Jawa:sepi ing pamrih, rame ing gawe, apabila ia dengan tenang, rendah hati (andhapasor) atau tanpa pamor dan pamer selalu memenuhi berbagai kewajibannya sehari-hari.Ia tidak lagi mengejar kepentingan-kepentingan individualnya tanpa memperhatikan keselarasan keseluruhan, maka ia berada di tempat yang tepat sesuai dengan maksud struktural funsionalnya dalam dunia kehidupan Jawa. Karenanya, Magnis Suseno menjelaskan bahwa, laba (keuntungan) bagi pedagang Jawa bukan dianggap sebagai kebutuhan demi memenuhi kepuasan diri sendiri. Tetapi, laba adalah sebagai kebutuhan yang dapat menyenangkan, membahagiakan dan atau menyelamatkan semua pihak (SDM dan SDA) yang terlibat di dunia kehidupannya. ${ }^{49}$

Mencermati berbagai penjelasan tersebut maka, tujuan efisiensi etos dagang orang Jawa adalah, barangkali di satu sisi (dalam cita ideal) menghendaki terciptanya keadaan keselarasan ekonomi (economic harmonis) dengan ahli efisiensi (efficiency engineer) yang dapat melahirkan suasanakemajuan yang manusiawisesuai pada masanya pada sisi lain. Winardi menjelaskan, keselarasan ekonomi (economic harmonis) artinya, kekutankekuatan yang bisa menimbulkan kemakmuran masyarakat secara keseluruhan, apabila setiap individu mengejar kepentingan sendiri. Kekuatan-kekuatan itu sepertidijelaskan Adam Smith, bukanlah berasal dari manusia melainkan manusia yang "dipimpin" oleh "tangan yang tak-kelihatan" (invisible hand) untuk membantu tercapainya tujuan yang bukan (yang mungkin?) merupakan bagian dari keinginannya. Adapun dimaksudkan ahli efisiensi (efficiency engineer) adalah orang yang ahli dalam bidang metode-metode produksi dan kepengawasan yang mengusahakan agar dihindari pemborosan dan ditentukan prosedur yang efektif. ${ }^{50}$ Menurut Magnis Suseno, maksudnya kemajuan yang

\footnotetext{
${ }^{48}$ Niels Mulder, Mysticism and Everyday Life in Contemporary Java, Cultural Persistence and Change, (Singapore: Singapore University Press, 1978), hlm. 37.

${ }^{49}$ Franz Magnis Suseno, Berfilsafat Dari...., op. cit., hlm. 86.

${ }^{50}$ Winardi, Kamus Ekonomi, (Bandung: Alumni, 1984),.hlm. 187..
} 
manusiawi yaitu, kemajuan hanya bersifat manusiawi apabila manusia menjadi lebih bebas dari penderitaan dan rasa takut, apabila ia merasa semakin tentram dan selamat, apabila ia sanggup untuk mewujudkn kehidupannya sebagai individu dalam lingkungannya sesuai dengan cita-citanya, apabila ia tidak diperbudak. ${ }^{51}$

Salah bukti tercapainya tujuan dalam dunia kehidupan etos dagang orang Jawa yang sesuai pada masanya tersebut, mungkin sebagaimana yang pernah diraih oleh kerajaan Mangkunegaran pada masa pemerintahan Mangkunegara IV. Kemungkinannya tersebut berdasarkan penilaian Pegeaud dan Pringgodigdo bahwa, kerajaan Mangkunegaran pada masa pemerintahan Mangkunegara IV berhasil meraih kemajuan di berbagai bidang kehidupan khususnya pada bidang perekonomian. Karenanya, di satu sisi raja Mangkunegara IV dinilai sebagai peletak dasar perekonomian Jawa modern dan pada masa pemerintahannya disebut sebagai Kala Sumbaga yang artinya, masa yang sangat sejahtera pada sisi lainnya, seperti telah dijelaskan di muka. Agar tujuan keberhasilannya tersebut dapat dipahami maksud dalamnya, maka perlu dibandingkan perspektif pemahamannya dengan budaya dagang keturunan Cina (etnis Cina).

Alasan perlu dibandingkan dengan budaya dagangnya keturunan Cina ada dua yaitu,pertama, menurut Lombard, hubungan perdagangan dan pertukaran budaya termasuk antara Jawa dengan Cina telah berlangsung sejak awal Masehi. Mencapai puncaknya pada abad XIII hingga XVII M sebelum VOC menancapkan hegemoni kekuasaannya di negeri ini. ${ }^{52} \mathrm{Kedua}$, berdasarkan pada kesimpulan penelitiannya Hana Tjandradiredja yang dilakukan selama tujuh tahun, sejak 1994 sampai 2001.Hasilnya telah dibukukan berjudul Budaya dan Strategi Berkarakteristik dalam Mencapai Keunggulan Pemasaran.Menurutnya, populasi masyarakat Indonesia pada saat ini berjumlah kurang lebih 200 juta orang yang dicirikan oleh dominannya produktivitas ekonomi oleh etnis Cina.Cerminannya cukup obyektif yaitu sekita 3\% keturunan Cina mewakili golongan menengahnya menguasai $90 \%$ kemampuan ekonomi di

\footnotetext{
${ }^{51}$ Franz Magnis Suseno, Kuasa dan...., op. cit., hlm. 155.

${ }^{52}$ Dennys Lombard, Nusa Jawa Silang Budaya: Jaringan Asia, jilid 2, (Jakarta: Gramedia, 1996), hlm. 88.
} 
Indonesia. ${ }^{53}$ Perspektif pemahamannya jika dibandingkan dengan etos dagang orang IslamJawa kurang lebih sebagai berikut.

\section{Perbandingan Pemahaman Etos Dagang Orang Islam Jawa dengan Budaya Dagang Etnis Cina}

Menurut sistem nilai moral Cina, seorang karyawan diharapkan sebagai pengikut, penurut dan acapkali sebagai seorang yang tidak perlu melalakukan banyak pertanyaan. Seorang pemimpin dianggap segalanya, paling pandai dari suatu kelompok ${ }^{54}$ Pertanyaan dan pendapat berbeda dianggap sebagai sikap mengganggu harga diri pimpinannya.Perilaku yang otoriter diharapkan datang dari superior sedangkan bawahan hanya bersifat pasif saja. ${ }^{55}$ Menurut Chan dan Moore, sikap masyarakat Cina pada lingkungan cenderung menerima daripada berusaha mengubahnya.Mereka mencari kecocokan dirinya kesamaan bagi suatu tindakan yang dapat membuat keharmonisan lingkungan. ${ }^{56}$ Hendry dan Fye menyimpulkan, bagi masyarakat Cina pembuatan keputusan secara perlahan-lahan dan setahap demi setahap.Masyarakat Cina bukan masyarkat yang mudah terpancing cepat untuk mengambil keputusan. ${ }^{57}$ Sikap masyarakat Cina itu searah dengan hasil penelitiannya Hana, dimana pedagang keturunan Cina mayoritas di Jawa tidak menyukai konsultasi dengan superiornya (pimpinan atau atasan).Hal tersebut wajar mengingat pedagang Cina sebagai minoritas dan sering kali mendapat perlakuan yang berbeda menjadikan mereka dalam bertindak lebih mempercayai kemampuan pribadinya. ${ }^{58}$

Landasan utama akan sikap tersebut nampaknya berkaitan erat dengan pandangan atas harga diri dari kehidupan masyarakat Cina seperti tersebut di muka. Menurut Chen, masyarakat Cina akan merasa terhina jika disentuh kehormatannya atau prestisenya. Norma kehidupan yang dianutnya, mereka berdasarkan kekeluargaan dan hubungan

\footnotetext{
${ }^{53}$ Hana Tjandradiredja, Budaya dan Strategi Berkarakteristik dalam Mencapai Keunggulan Pemasaran, (Jakarta: Lembaga Penerbit Fak. Ekonomi UI, 2002), hlm. 102.

${ }^{54}$ Stephen Martin, Industrial Economic: Economic Analysis and Public Policy, (New York: Mac Millan Publ. Company, 1989), hlm. xxi.

${ }^{55}$ Ibid.,hlm. 75.

${ }^{56}$ Nikhilesh Dholakia (ed.), Marketing as If Culture Mattered, (University of Rhode Island: University of Rhode Press, 1987), hlm. 55.

${ }^{57}$ Stepehen Martin, Industrial Economi...., op. cit., hlm. 76.

${ }^{58}$ Hana Tjandradiredja, Budaya dan Strategi...., op. cit., hlm. 137.
} 
antarpribadi yang saling ketergantungan satu sama lainnya. Eksistensi individu dalam masyarakat Cina harus dihargai atau dihormati.Kondisi tersebut memberi konsekuensi bahwa, jenjang hierarki sebagai lambang kehormatan menentukan tanggung jawab seseorang. Norma itu hampir sama dengan yang dianut masyarakat Jepang. ${ }^{59}$ Acuan norma dalam bersikapnya tersebut berdampak pada strategi penggunaan sumber daya stakeholders terutama bagi pengendalian lingkungan dan penggunaan informasi. Menurut hasil penelitian Hana, pedagang keturunan Cina cenderung bersikap mencari dan mengendalikan lingkungan seperti budaya Barat.Keadaansebenarnya tidak masalah, artinya, kecenderungan untuk melakukan negoisasi dan tawar-menawar dalam memecahkan permasalahan penggunaan sumber daya untuk mengendalikan lingkungan lebih besar. Sikapnya tersebut juga berdampak dalam hal menghadapi persaingan yang disebabkan adanya pertukaran antara berbagai pihak lain yang terlibat dalam dunia perdagangan. ${ }^{60}$

Menurut Hana, dalam budaya Barat pertukaran didasarkan pada prinsip keseimbangan dan hubungan khusus, sedang dalam budaya Cina hal itu didasarkan pada keterikatan moral jangka panjang, dalam hal ini hutang budi merupakan bentuk pertukaran jangka panjang yang tidak pernah dilupakan. Oleh karena itu, hubungan kerjasama selalu didasarkan pada kekeluargaan. Perdagangan yang dibangun oleh keluarga-keluarga Cina berdasar pada kepercayaan pribadi atau guanxie yang berarti, ikatan manusia yang bersifat pribadi, khas, dan non-idiologis, tetapi karena kesamaan identitas. Kesamaan tersebut akan lebih diprioritaskan di lingkungan keluarga, marga, dan atau leturunan Cina-nya baru kemudian ke arah kesamaan lain, misalnya agama atau daerah. Sikap-sikapnya tersebut telah menjadi spontanitas etos kerjanya, termasuk dalam dagangnya melekat secara turun-temurun. ${ }^{61}$ Berbagai sikapnya tersebut mesti juga berhubungan erat dengan etika dalam menghadapi berbagai masalah sosial.

Bagi masyarakat Cina dengan berprinsip pada Konfusianisme, etika dalam melihat permasalahan demi keberhasilan lebih mengutamakan pada idealisme moral dan

\footnotetext{
${ }^{59}$ Nikhiles Dholakia (ed.), Marketing as If ...., op. cit., hlm. 57-59.

${ }^{60}$ Hana Tjandradiredja, Budaya dan Strategi...., op. cit., hlm. 138-139.

${ }^{61}$ Ibid., hlm. 143.
} 
menempatkan hukum sosial di atas pertimbangan kegunaannya. ${ }^{62}$ Menurut Luthans, pandangan demikian itu digolongkan pada etika utilitarianisme ideal adalah, suatu bentuk etika yang menekankan konsekuensi atas satu tindakan yang dapat dinilai dengan mempertimbangkan aspek yang lebih luas, seperti nilai internal manusia serta hubungan teman serta pengetahuannya. ${ }^{63}$

Penjelasan terakhir tersebut jika dihubungkan dengan pedagang keturunan Cina di Jawa, seperti hasil penelitian Hana, disebutkan bahwa mereka memiliki kecenderungan etika utilitarianisme yang tinggi. Para pedagang keturunan Cina menilai lembaga, hukum, konsistensi dalam prinsip, serta kebiasaan dianggap cukup penting demi menentukan suatu konsekuensi dalam dagangnya terhadap masyarakat. Disimpulkan bahwa, semangat moral atau etika dagangnya keturunan Cina di Jawa cenderung bersifat maskulin artinya, tindakan-tindakannya lebih rasional dan atau lebih diperhitungkan untung rugi dalam menilai suatu konsekuensi dari tindakannya tersebut. ${ }^{64}$

Menurut kesimpulan Hana selanjutnya, hubungan manajemen stakeholders approach dengan sub-variablenya, baik budaya dagang keturunan Cina maupun Jawa memiliki pandangan yang cenderung sama. Keduanya berpandangan dalam cara untuk berusaha menjaga hubungan baik dengan para pelanggan, konsumen, pemasok, pemerintah (superior) dan lingkungannya. Caranya itu merupakan manifestasi norma kehidupan berdasarkan pada kehormatan dan keharmonisan. Namun, berbeda dalam hal hubungannya dengan situasi keputusan pemasaran yang penuh resiko karena persaingan dagang yaitu masuknya pendatang baru, ancaman produk pengganti, kekuatan tawar menawar antar pembeli dan pemasok. Kasus situasi pemasaran sehingga diketahui apakah perlu melakukan kerja sama sebagai bagian menjaga hubungan baik, atau tidak sama sekali, atau kombinasi keduanya. ${ }^{65}$

Menurut hasil penelitian Hana, dalam keadaan nyata pemasarannya para pedagang pribumi asli (Jawa) cenderung bersikap mengajak para pendatang baru untuk bekerja

\footnotetext{
${ }^{62}$ Nikhiles Dholakia (ed.), Marketing as If...., op. cit., hlm. 57.

${ }^{6363}$ Fred Luthans (ed.), Organizational Behavior, (New York: McGraw Hill Book Company, 4 th ed., 1985),

${ }^{64}$ Hana Tjandradiredja, Budaya dan Strategi...., op. cit., hlm. 150.

${ }^{65}$ Ibid.,hlm. 151.
} hlm. 76. 
sama. Sedangkan para pedagang keturunan Cina cenderung untuk mengerahkan kemampuannya secara optimal tanpa melakukan kerja sama. Cara bersikap demikian bisa saja terjadi karena dalam suatu pertukaran kerja sama dibutuhkan ikatan sosial jangka panjang. Mungkin hal itu dianggap lebih berat oleh pedagang keturunan Cina yang mendasarkan diri pada hutang budi secara moral sulit dibayar dan dilupakan. Terkait dalam hal itu dengan resiko, bagi pedagang pribumi asli nampaknya memiliki penilaian bahwa, resiko dapat disesuaikan atau dikurangi melalui kerja sama. Namun sebaliknya, bagi pedagang keturunan Cina menilai hal itu tanpa harus kerja sama, maksudnya mereka lebih berani menanggung resiko sendiri tanpa melibatkan pihak lain. Bagi mereka, resiko dapat diatasi dengan menggunakan cara lain misalnya, dengan mengendalikan sendiri dan efisiensi dalam hal waktu dan dana atau sumber daya lainnya. ${ }^{66}$

Mencermati penjelasan terakhir tersebut mengimplikasikan karakteristik atau sifat dagangnya etnis Cina cenderung kedalamegoisme etis. Menurut Mudhofir, egoisme etismengandung tiga arti yaitu,orang seharusnya bertujuan untuk meningkatkan kesejahteraan dan kepentingannya sendiri. Kedua, yang terbaik bagi kehidupan seharusnya memperoleh yang paling memuaskan atau yang paling menyenangkan terhadap dirinya sendiri.Ketiga, semua tindakan manusia secara disadari atau tidak didorong oleh hasrat bagi kesejahteraan dan kepuasan dirinya sendiri. Hanya nampaknya saja tindakan seseorang itu untuk kepentingan orng lain. ${ }^{67}$ Motivasi dan maksuddagang etnis Cina tersebut, di satu sisi caranya bertindak memang lebih cenderung sesuai dengan rame ing gawe. Namun pada sisi lainnya, etos dagangnya bertentangan dengan sepi ing pamrih, sehingga nilai moral tindakan dagangnya egoisme etis yang maknanya sama dengan bertindak karena pamrih. Makna tindakandemikian itu tidak dapat melahirkan kemajuan yang manusiawi karena di satu pihak, menurut Magnis Suseno, pasar dunia sekarang dalam etika pasar bebas yang berjalan dengan era globalisasi ekonomi di sampingitu padapihak lainnya,kondisi negara Indonesia sekarang sedang mengalami krisis ekonomidan jugasebagai negara pascakolonial (postcolonial state). ${ }^{68}$

\footnotetext{
${ }^{66}$ Ibid., hlm. 153.

${ }^{67}$ Ali Mudhofir, Teori dan Aliran dalam Filsafat dan Teologi, (Yogyakarta: UGM Press, 1996), hlm. 55.

${ }^{68}$ Franz Magnis Suseno, Pijar-Pijar Filsafat...., op. cit., hlm. 175.
} 
Menurut K. Bertens, era globalisasi ekonomi adalah, kegiatan ekonomi mencakupseluruh dunia, sehingga hampir semua negara tercantum dalam"pasar" sebagaimana dimengerti sekarang dan merasakan akibat pasang surutnya pasar ekonomis. ${ }^{69}$ Maksudnya krisis ekonomiadalah, konflik laten antar kelas menimbulkan berbagai masalah dengan berbagai cara dan yang mengemudikan proses perekonomian. ${ }^{70}$ Maksudnya negara pascakolonial yaitu, sebuah negara yang masih dipengaruhi secara signifikan baik secara politik, ekonomi maupun kultural oleh sang kolonial. ${ }^{71}$ Penjelasan tentang berbagai pengertian tersebut mengimplikasikan pemahaman dampaknya bahwa,apabilasifat dagangnya etnis Cina egoisme etis seperti tersebut di atas, maka mungkin cenderung mudah menimbulkanspiral kekerasan daripada semangat bagietos perjuangan tanpa kekerasan.Maksudnyaspiral kekerasan yaitu, suatu kekerasan yang menimbulkan kekerasan lain dan sumber utamanya yaitu, ketidakadilan. Kekerasan pertamamendorong kekerasan bentuk kedua: pemberontakan masyarakat sipil, dan kekerasan kedua mengakibatkan kekerasan ketiga, represi Negara. Sedangkan sikap perjuangan tanpa kekerasan artinya suatu strategi perjuangan alternatif yang menaruh sikap hormat pada moralitas lawan. ${ }^{72}$ Kemungkinan masalah terpenting pada kecenderungan sifat dagangnya etnis Cina tersebut dengan kondisi perekonomian sekarang: dalam era globalisasi ekonomi, maka cenderung mengandung duakekurangan. Pertama, kurang realistis dan rasional, dan yangkedua, kurang sesuai dengan identitas budaya atau pengalaman keagamaan orang Islam Jawa yang dalam masyarakat pascakolonial.

Karena, etos dagang orang Jawa yang terungkap dalam nilai-nilai moral budya Jawa dan yang pernah dipraktekkan dalam dunia kehidupan yang sesuai pada masanya sebagaimana dalam pemerintahan dan pemikiran raja Mangkunegara IV seperti diurai pada tulisan ini, kiranya pantas menawarkan diri sebagai bagian alternatif pemecahannya. Misalnya, pertama-tama,kedua belah pihak baik pedagang etnis Cina maupun orang Jawa, sebaiknya selalu melakukan proses dialogis partisipatif transendental dalam dunia

\footnotetext{
${ }^{69}$ K. Berten, Pengantar Etika...., op. cit., hlm. 347.

${ }^{70}$ Franz Magnis Suseno, Pijar-Pijar Filsafat...., op. cit., hlm. 183.

${ }^{71}$ Fitzgeraid K, Sitorus,"Identitas Dekonstruksi Permanen”, dalam: Muji Sutrisno dan Hendar Putranto (ed.), Hermeneutik Pascakolonial Soal Identitas, (Yogyakarta: Kanisius, 2004), hlm. 170.

${ }^{72}$ Siswanto Masruri, Humanitarianisme Soedjatmoko Visi Kemanusiaan Kontemporer, (Yogyakarta: Pilar, 2005), hlm. 388-389.
} 
kehidupan atau realitas sosial yang sesuai pada masanya. Kedua, proses tersebut teknis pemberdayaannya harus disesuaikanbaik antara proses pendidikan dengan budaya maupun dengan pengalaman keagamaan Islam Jawa. Dua contoh alternatif itu seperti yang diberdayakan dalam pemikiran raja Mangkunegara IVmelalui tujuh sikap dan lima sifat serta delapan macam cara bersikap etis yang berguna(Asta Gina)seperti telah dijelaskandi muka. Pemikiran-pemikiran raja Mangkunegara IV itu pernah dipraktekkan dalam kehidupan sosialnya terutama di bidang dagang yang sesuai pada masanya.

Nilai-nilai moral pada pemikiran-pemikiran raja Mangkunegara IV tersebut, mengimplikasikan kedalaman makna etos dagang orang Jawa adalah sikap maskulin. Hal itu seperti dijelaskan Budi Paramita, sikap yang dikembangkan orang Jawa adalah sikap maskulin adalah, rasional dengan memperhitungkan untung rugi, konsisten dalam prinsip serta berpikir logis dalam meninjau baik masa lampau dan masa depan, memiliki keinginan akan keberhasilan, kepahlawanan, keyakinan dan konsekuen atas keuntungan materi. Lawan dari sikap maskulin adalahfeminin dalam dagang artinya, aktivitasnya lebih memperhitungkan maksud yang diinginkan tanpa mempertimbangkan materi atas tindakan, lebih mementingkan hubungan teman, menekankan masa lampau daripada masa depan, berperilaku sederhana, memperhatikan yang lemah dan mementingkan mutu hidup agar lebih langgeng, lebih sama rata. ${ }^{73}$ Budaya dagang etnis Cina cenderung bersikap feminin daripada maskulin sebagaimana telah dijelaskan di muka.Memperhatikan penjelasan tersebut, maka sifat feminin lebih tinggi dalam dagang maka bisa menghasilkan keunggulan yang lebih rendah.Karena prinsip bahwa maskulin merupakan karakteristik pria, sedangkan feminin sebagai karakteristiknya wanita. Sebagaimanadijelaskan Cottle, pria memiliki orientasi pasar lebih tinggi dibanding wanita, dalam arti pria lebih memilki orientasi ke masa depan. ${ }^{74}$

\section{Kesimpulan}

Memperhatikan berbagai penjelasan tersebut dapat disimpulkan bahwa para pedagang Jawa, baik etnis Cina maupun pribumi asli, kinerja bisnisnya sebaiknya berdasar pada etos dagangnya orang Islam Jawa yang terungkap dalam nilai-nilai moral budya Jawa dan yang

\footnotetext{
${ }^{73}$ Budi Paramita, Struktur Organisasi di Indonesia, (Jakarta: Lembaga Penerbit Fak. Ekonomi UI, 1985), hlm. 77.

${ }^{74}$ Fred Luthans (ed.), Organizational...., op. cit., hlm. 57.
} 
pernah dipraktekkan di dunia kehidupan yang sesuai pada masanya sebagaimana dalam pemerintahan dan pemikiran raja Mangkunegara IV. Dengan demikian dimungkinkan atau diharapkan etos dagangnya orang Islam Jawa meningkat terutama dalam aspek penjualan, keuntungan serta pelanggannya.Berdasarkan kemungkinan peningkatan tersebut, maka etos dagang orang Islam Jawa dapat menjadi kerangka acuan tantangan selanjutnya dan sebagaisumbangan pemikiran peningkatan perekonomian Jawa Tengan khususnya dan Nasional pada umumnya. 


\section{DAFTAR PUSTAKA}

Antlov, Hans dan Sven Cederroth (ed.), Kepemimpinan Jawa Perintah Halus Pemerintahan Otoriter, Jakarta: YOI, 2001.

Bagus, Lorens, Kamus Filsafat, Jakarta: Gramedia, 2000.

Bertens, K, Pengantar Etika Bisnis, Yogyakarta: Kanisisus, 2000. ,Etika, Jakarta: Gramedia, 2005.

Ciptoprawiro, Abdullah, Filsafat Jawa, Jakarta: Balai Pustaka, 2000.

Daryono, Etos Dagang Orang Jawa Pengalaman Raja Mangkunegara IV, Yogyakarta: Pustaka Pelajar, 2007.

Dholakia, Nikhilesh (ed.), Marketing as If Cultur Mattered, University of Rhode Island: University of Rhode Preess, 1987.

Flew, Antony (ed.), A Dictionary of Philosophy, New York: St. Martin's Press, 1987.

Gertz, Clifford,"The Impact of the Concept of Cultur on the Concenp of Man", dalam John R. Platt (ed.), New Views of the Nature of Man, Chicago: The University of Chicago Press, 1965.

Kodiran,"Kebudayaan Jawa",dalam: Koentjaraningrat (ed.), Anthrophology in Indonesian A Bibliograpical Review, 's-Gravenhage: Martinus Nijhoff, 1995.

Lombard, Dennys, Nusa Jawa Silang Budaya: Jaringan Asia, jilid 2, Jakarta: Gramedia, 1996.

Mangkunegara IV,"Serat Darmalaksita",dalam: Ki Padmasusastra, Dwidja Isjwara, Surakarta: Albert Rusche, 1889.

Martin, Stephen, Industrial Economic, Economic Analysis and Public Polisy, New York: Mac Millan Publ. Company, 1987.

Masruri, Siswanto, Humanitarianisme Soedjatmoko Visi Kemanusiaan Kontemporer, Yogyakarta: PILAR, 2005. 
Moertono, Soemarsaid, Negara dan Usaha Bina Negara di Jawa Masa Lampau, Jakarta: YOI, 1985.

Mubyarto, Ekonomi Pancasila, Jakarta: LP3ES, 1993.

Mudhofir, Ali, Teori dan Aliran dalam Filsafat dan Teologi, Yogyakarta: UGM Press, 1996.

Mulder, Niels, Mistisisme Jawa Ideologi Indonesia, terj. Noor Cholis, Yogyakarta: Lkis, 2001.

Paramita, Budi, Struktur Organisasi di Indonesia, Jakarta: Lembaga Penerbit Fakultas Ekonomi UI, 1985.

Peale, Kennecth Blanchard dan Norman Vincent, The Power of Ethical Management, London: Cedar Ltd., 1991.

Pegeaud, Th.G,"Pangeran Adipati Arja Mangkoenagara IV als Dichters", terj. R.Tg.Muhamad Husodo Pringgokusumo, dalam: Djawa, no. 4, Agustus 1927.

Pringgodigdo, R.M.Mr.A.K, Sejarah Perusahaan-Perusahaan Mangkunegara, terj. R.Tg. Muhamad Husodo Pringgokusumo, Surakarta: Yayasan Mangadeg Mangkunegaran, 1987.

Soetrisno, Falsafah Hidup Pancasila sebagaimana Tercermin dalam Falsafah Hidup Orang Jawa, Yogyakarta: Pandawa, 1977.

Sumodiningrat, Gunawan,"Budaya Jawa dan Integrasi Nasional",dalam: Laela Retna Kumala (ed.),Keraton Surakarta dan Perubahan Masyarakat, Membumikan Nilai-nilai Tradisional, Surakarta: Team Simposium Nasional, 2003.

Suseno, Franz Magnis, Pijar-pijar Filsafat dari Gatholoco ke Filsafat Perempuan dari Adam Muller ke Postmodernisme, Yogyakarta: Kanisius, 2005.

, Etika Jawa sebuah Analisa Faksafi Kebijakan Hidup Jawa, Jakarta: Gramedia, 2001.

, Kuasa dan Moral, Jakarta: PT SUN, 2001.

, Berfilsafat dari Konteks, Jakarta: Gramedia, 1992. 
Tjandradiredja, Hana, Budaya dan Strategi Berkarakteristik dalam Mencapai Keunggulan Pemasaran, Jakarta: Lembaga Penerbit Fak. Ekonomi UI, 2002.

Winardi, Kamus Ekonomi, Bandung: Alumni, 1984. 